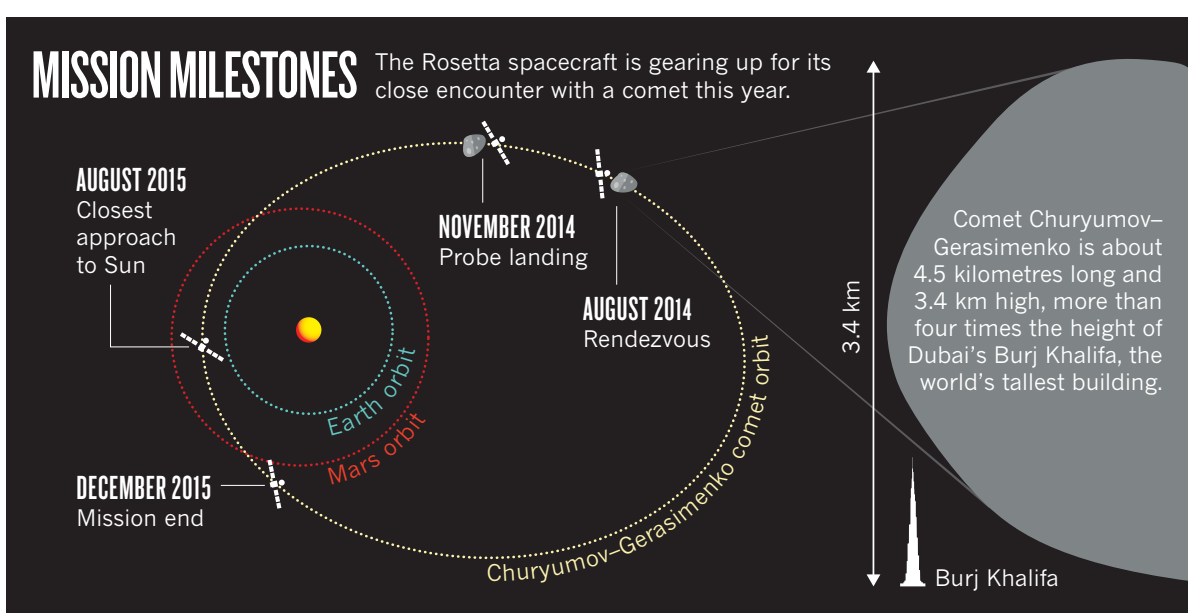

> 'Mission milestones'). "We really know very little about this object," says Andrea Accomazzo, Rosetta's spacecraft-operations manager.

ESA plans to release Philae in November, before the comet - already spewing gas and dust - gets too close to the Sun, when it will start to produce more debris. Rosetta, which will ordinarily orbit at up to 100 kilometres from the comet, will descend to about 4 kilometres away for the landing, and will drop its instrument-laden probe unpowered into a zone about one kilometre squared. With just one shot at the landing, which will be automated because of a 30-minute delay in communications with Earth, the operation will be risky. "Even though we will have chosen the best possible site, we'll still need some luck to land on a safe part," says Mark McCaughrean, senior scientific adviser at the ESA directorate of science and robotic exploration. Rosetta will circle the comet at the equivalent of walking pace, albeit as both hurtle along at 20 kilometres per second.

Once Philae has secured itself on the surface using a harpoon, its batteries will last a few days; after this it must survive on solar power, which will be difficult once its panels are covered in dust. "We really don't know how long it will last," says McCaughrean. Although the emphasis will be on the lander's performance, just getting the orbiting spacecraft and its complex instruments into position around the comet will be a big success, he says. "If we put the lander on the surface, that's the cherry on the cake."

Comets are primitive objects. Their gas, dust and organic molecules have changed little since their creation along with the Solar
System 4.6 billion years ago. Scientists think that they hold strong clues about its origins. Comets are also thought to have delivered a large fraction of Earth's water, and possibly amino acids, the building blocks of life.

Assuming all goes to plan, cameras and sensors on the orbiter will examine the comet in detail over the next year, while spectrometers analyse the chemistry of its dust. The lander will look at the comet's surface composition and structure. Both will assess the ratio of normal to heavy water - formed from the hydrogen isotope deuterium - to see if comet ice matches Earth's water signature, and their instruments will hunt for the complex organic molecules that are needed to assemble primitive life.

Uwe Meierhenrich, an analytical chemist at the University of Nice Sophia Antipolis in France, will be anxiously waiting for the results. He is co-investigator of Philae's COSAC (Cometary Sampling and Composition) experiment, which will analyse materials from around 20 centimetres beneath the comet's surface. These might include organic materials that do not vaporize and never form part of the gas tail that astronomers can study from Earth.

COSAC will also measure the chirality (or 'handedness') of any detected amino acids, something that is impossible through remote observation and has never been done before on comet samples, says Meierhenrich. On Earth, amino acids in proteins are left-handed, so finding a predominance of left-handed molecules on the comet would add weight to theories that such a cosmic traveller seeded life on Earth by providing essential basic ingredients.

\title{
Researchers question rescued polar expedition
}

\section{Australian Antarctic Division says it did not approve research strategy of stricken mission.}

\section{BY ALEXANDRA WITZE}

$\mathrm{T}$ he Australian Antarctic Division (AAD) has added its voice to the growing criticism of a stricken private polar expedition by challenging claims that it approved the research element of the trip.

On page 291 of this issue, Nick Gales, chief scientist of the AAD, which is based in Kingston, Tasmania, responds to an earlier Nature column by expedition head Chris Turney of the University of New South Wales (see Nature 505, 133; 2014). Turney's Australasian Antarctic Expedition aimed to retrace the steps of explorer Douglas Mawson, who led an outing a century ago. But members of Turney's expedition had to be rescued from their ship, the $M V$ Akademik Shokalskiy, after it became trapped in ice at Christmas, adding fuel to a debate about the merits of such privately funded trips.

Gales challenges Turney's implicit suggestion that the AAD had approved the expedition's science plan. The AAD did not formally review the research strategy, Gales notes, but had issued the permits required for Turney's group to visit the region in which it got stuck. "It's an important distinction for us," says Gales. He adds that the expedition's rescue has delayed several projects in Australia's national Antarctic programme that have been many years in the planning.

Other polar scientists have criticized the ninepoint science plan laid out on the expedition's website. The plan "could be interpreted as delivering outcomes that I believe are not possible from this single voyage", says Richard Coleman, deputy director of the Institute for Marine and Antarctic Studies at the University of Tasmania in Hobart, Australia. For instance, the plan's first bullet point says that the expedition aims to "gain new insights into the circulation of the Southern Ocean and its impact on the global carbon cycle". A single trip could provide only 


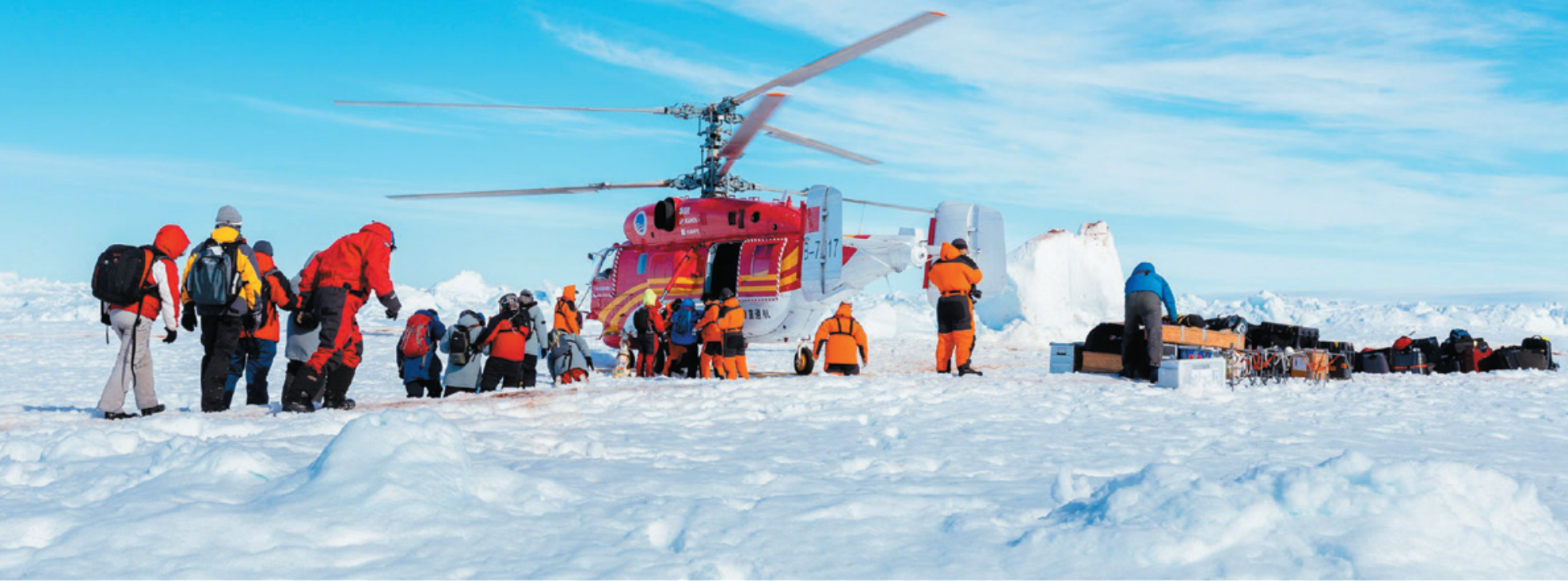

Members of the Australasian Antarctic Expedition are rescued by a Chinese helicopter after their ship, the MV Akademik Shokalskiy, became trapped in ice.

$\frac{\infty}{0}$ limited glimpses into this massive question, says Coleman, who sits on the committee that evaluates research proposals for the AAD.

Turney, Gales and others all agree that the scientific value of the expedition will be measured in the quality of peer-reviewed science it produces. Yet the expedition's fate has sharpened the long-standing tension between government polar-research programmes, which typically follow strategic plans devised through many rounds of peer review, and private voyages, which occasionally have science objectives along with other goals such as tourism or raising i environmental awareness.

Turney says that he regrets any confusion over the AAD's involvement in the expedition. "At no stage did I intend to convey the impression that the [expedition] projects had been subject to the competitive peer-reviewed process required for participants in the formal Australian Antarctic programme," he says.

The Russian-registered Shokalskiy became trapped on 24 December in thick ice in the Commonwealth Bay region. The vessel's captain put out a distress call, and Australian, Chinese, French and US ships interrupted their schedules and came to help.

On 2 January, the 52 scientists, students, educators and journalists aboard the Shokalskiy evacuated to the Australian vessel Aurora Australis aboard a helicopter provided by the Chinese icebreaker Xue Long, which had also

become stuck in ice while attempting to reach the stricken Shokalskiy. The complex maritime emergency ended a few days later when the Xue Long and the Shokalskiy both managed to extricate themselves. The Xue Long continued on its way to scout the Ross Sea region for the site of a future Antarctic base, China's fifth.

The Australis travelled to Australia's Casey Antarctic base, where it had been working before the rescue, with its new passengers. The diversion has put it behind schedule, delaying the resupply of several of Australia's polarresearch stations. A Casey-based project to study ocean acidification did not receive the diving equipment it needs to scout sites

"We are now
faced with
the difficult
situation of how
to salvage our
own project."
for a carbon dioxide enrichment experiment to be carried out this year, among other delays.

"The reduction in available field time for this season has set us back significantly and we will not achieve all of our goals for this summer," says Donna Roberts, the acidification project's chief investigator and a senior research fellow at the Antarctic Climate and Ecosystems Cooperative Research Centre in Hobart. "We are now faced with the difficult situation of how to salvage our own project."

Like other governments involved in Antarctic research, Australia has a long-term strategic science plan built around testable hypotheses to answer key questions, says Mahlon Kennicutt, a Texas-based oceanographer and former president of the Scientific Committee for Antarctic Research. "Those that have invested great time and energy to pass the high bar of national funding see their programmes being jeopardized by those that might be perceived to have circumvented the system," he says.

But expedition participant Janet Wilmshurst, a palaeoecologist at Landcare Research in Lincoln, New Zealand, argues that the expedition has brought back important science. Before reaching Antarctica, it explored the subantarctic islands of New Zealand. Wilmshurst led a team that gathered peat cores, leaf and soil litter and other samples to study environmental change.

"It was incredibly productive for us," she says. For instance, three new peat cores from the Snares Islands will be the first from the island group to be analysed using modern techniques, providing a glimpse into climate history at a key location where the northern Southern Ocean meets a subtropical front.

Sorting out the long-term research effects of the Shokalskiy rescue may take some time. "My biggest concern is that of the reputation for Antarctic science," says Patrick Quilty, a geologist at the University of Tasmania who has worked in Antarctica for nearly five decades. "There are ramifications."

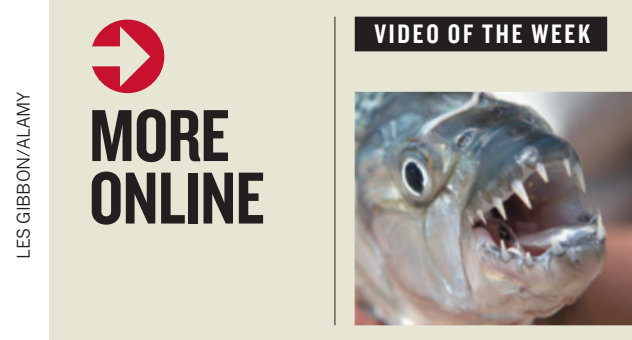

Freshwater fish jumps to catch bird out of the air go.nature.com/ vc9kww

\section{MORE NEWS}

- Ground shifted 50 centimetres before Icelandic volcano erupted go.nature.com/mavw3u

- Nineteenth-century strain of cholera is rarely seen today go.nature.com/yaiol5

- More than 180 fish species are biofluorescent go.nature.com/iswnnj

\section{NATURE PODCAST}

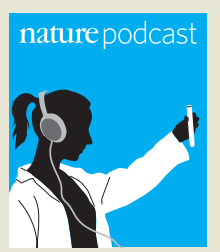

Why birds fly in $\checkmark$ formation, old trees sequester more carbon, and the FDA's decision on 23 andMe nature. com/nature/podcast 